\title{
SARS-CoV-2 neutralising antibody testing in Europe: towards harmonisation of neutralising antibody titres for better use of convalescent plasma and comparability of trial data
}

Dung Nguyen $^{1}$, Peter Simmonds ${ }^{1}$, Maurice Steenhuis ${ }^{2}$, Elise Wouters ${ }^{3}$, Daniel Desmecht ${ }^{4}$, Mutien Garigliany ${ }^{4}$, Marta

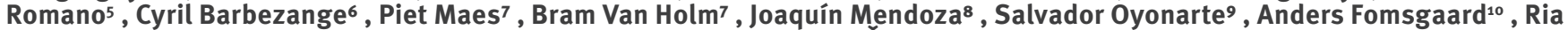

Lassaunière $^{10}$, Eva Zusinaite ${ }^{11}$, Katarina Resman Rus ${ }^{12}$, Tatjana Avšič-Županc ${ }^{12}$, Johan HJ Reimerink ${ }^{13}$, Fiona Brouwer ${ }^{13}$, Marieke

Hoogerwerf ${ }^{13}$, Chantal BEM Reusken ${ }^{13}$, Gunnveig Grodeland ${ }^{14}$, Sophie Le Cam ${ }^{15}$, Pierre Gallian ${ }^{15,16}$, Abdennour Amroun ${ }^{16}$,

Nadège Brisbarre ${ }^{16,17}$, Christophe Martinaud ${ }^{18}$, Isabelle Leparc Goffart ${ }^{19}$, Hubert Schrezenmeier ${ }^{20,21}$, Hendrik B Feys ${ }^{3}$, C Ellen van der Schoot ${ }^{2}$, Heli Harvala ${ }^{22,23}$

1. University of Oxford, Oxford, United Kingdom

2. Department of Immunopathology, Sanquin Research and Landsteiner Laboratory Academic Medical Centre, Amsterdam, Netherlands

3. Transfusion Research Centre, Belgian Red Cross-Flanders, Ghent, Belgium

4. Department of Pathology, Faculty of Veterinary Medicine, Liège University, Liège, Belgium

5. Immune Response service, Sciensano, Brussels, Belgium

6. National Influenza Centre, Sciensano, Brussels, Belgium

7. KU Leuven, Rega Institute, Clinical and Epidemiological Virology, Leuven, Belgium

8. Vircell SL, Granada, Spain

9. Andalusian Network of Transfusion Medicine, Tissues and Cells, Sevilla, Spain

10. Virus and Microbiological Special Diagnostics, Statens Serum Institute, Copenhagen, Denmark

11. Tartu University Institute of Technology, Tartu, Estonia

12. Institute of Microbiology and Immunology, Ljubljana, Slovenia

13. Centre for Infectious Disease Control, WHO COVID-19 Reference Laboratory, RIVML, Bilthoven, the Netherlands

14. Dep. of Immunology, University of Oslo and Oslo University Hospital, Oslo, Norway

15. Etablissement Français du Sang, La Plaine Saint Denis, France

16. Unité des Virus Émergents (Aix-Marseille University - IRD 190 - Inserm 1207 - IHU Méditerranée Infection), Marseille, France

17. Etablissement français du Sang Provence Alpes Côte d'Azur et Corse, Marseille, France

18. Centre de Transfusion Sanguine des Armées, Clamart, France

19. Unité de Virologie, Institut de Recherche Biomédicale des Armées, Marseille, France

20. Department of Transfusion Medicine, Ulm University, Ulm, Germany

21. Institute for Clinical Transfusion Medicine and Immunogenetics, German Red Cross Blood Transfusion Service Baden-

Wurttemberg - Hessen and University Hospital Ulm, Ulm, Germany

22. Microbiology Services, NHS Blood and Transplant, Colindale, United Kingdom

23. University College of London, London, United Kingdom

Correspondence: Heli Harvala (heli.harvalasimmonds@nhsbt.nhs.uk)

Citation style for this article:

Nguyen Dung, Simmonds Peter, Steenhuis Maurice, Wouters Elise, Desmecht Daniel, Garigliany Mutien, Romano Marta, Barbezange Cyril, Maes Piet, Van Holm Bram, Mendoza Joaquín, Oyonarte Salvador, Fomsgaard Anders, Lassaunière Ria, Zusinaite Eva, Resman Rus Katarina, Avšič-Županc Tatjana, Reimerink Johan HJ, Brouwer Fiona, Hoogerwerf Marieke, Reusken Chantal BEM, Grodeland Gunnveig, Le Cam Sophie, Gallian Pierre, Amroun Abdennour, Brisbarre Nadège, Martinaud Christophe, Leparc Goffart Isabelle, Schrezenmeier Hubert, Feys Hendrik B, van der Schoot C Ellen, Harvala Heli. SARS-CoV-2 neutralising antibody testing in Europe: towards harmonisation of neutralising antibody titres for better use of convalescent plasma and comparability of trial data. Euro Surveill. 2021;26(27): pii=2100568. https://doi.org/10.2807/1560-7917.ES.2021.26.27.2100568

Article submitted on 11 Jun 2021 / accepted on 05 Jul 2021 / published on 05 Jul 2021

We compared the performance of SARS-CoV-2 neutralising antibody testing between 12 European laboratories involved in convalescent plasma trials. Raw titres differed almost 100-fold differences between laboratories when blind-testing 15 plasma samples. Calibration of titres in relation to the reference reagent and standard curve obtained by testing a dilution series reduced the inter-laboratory variability ca 10 -fold. The harmonisation of neutralising antibody quantification is a vital step towards determining the protective and therapeutic levels of neutralising antibodies.
Individuals infected with severe acute respiratory syndrome coronavirus 2 (SARS-CoV-2) develop a neutralising antibody response, which is a key component of adaptive immunity and considered a primary mechanism of protection against many vaccine-preventable infections [1-5]. Neutralising antibodies can also be used as therapeutics, via passive transfer of monoclonal or polyclonal antibodies to prevent or cure infections [6-9]. Convalescent plasma containing a sufficient level of neutralising antibodies has been successfully used as a prophylactic or early treatment for SARS-CoV-2 infection [10-12]. However, neutralising antibody testing has not been standardised and hence titres obtained in one study cannot be compared with 
TABLE 1

Details of samples referred for external evaluation of anti-SARS-CoV-2 neutralising antibody testing $(n=10)$

\begin{tabular}{|c|c|c|c|c|}
\hline Convalescent plasma sample & Included in the panel & Neutralising antibody titre & EUROImmun S/Co ratio & Date of sampling \\
\hline 12 & Twice & 80 & $4 \cdot 32$ & 15 Aug 2020 \\
\hline 7 & Twice & 160 & 5.27 & 31 Jul 2020 \\
\hline 19 & Twice & 640 & 5.90 & 26 Nov 2020 \\
\hline 13 & Twice & $<20$ & 0.12 & 2 Sep 2020 \\
\hline $1 \mathrm{~A}$ (neat) & Once & 5,120 & 7.06 & 3 Aug 2020 \\
\hline $1 B(1: 10)$ & Once & 320 & 3.86 & 3 Aug 2020 \\
\hline $1 C(1: 50)$ & Once & 80 & 1.12 & 3 Aug 2020 \\
\hline $1 \mathrm{D}(1: 100)$ & Once & 40 & 0.11 & 3 Aug 2020 \\
\hline NIBSC $1: 10(130 \mathrm{IU} / \mathrm{mL})^{a}$ & Once & 160 & 1.94 & NA \\
\hline
\end{tabular}

IU: international units; NIBSC: National Institute for Biological Standards and Control; SARS-CoV-2: severe acute respiratory syndrome coronavirus 2; S/Co: signal to cut-off ratio.

a NIBSC research reagent code $20 / 130$.

those obtained in others. Here we describe SARS-CoV-2 live virus neutralisation testing and its standardisation across 12 laboratories in nine European countries in order to harmonise titres applied in convalescent plasma trials and for potential future use.

\section{Panel of convalescent plasma samples}

We constructed and provided for blinded testing a panel of 15 SARS-CoV-2 convalescent plasma samples obtained from six individuals in England; the samples had varying neutralising titres in the in-house live virus neutralising assay and reactivity in the Eurolmmune anti-spike IgG ELISA (PerkinElmer, London, United Kingdom) (Table 1). The panel included a 1:10 dilution of research reagent 20/130 obtained from the National Institute for Biological Standards and Control (NIBSC, United Kingdom) which had been assigned a unitage of 1,300 international units (IU)/mL of SARS-CoV-2neutralising antibodies [12]. A dilution series of a hightitre convalescent plasma sample (Sample 1; dilutions labelled as $1 \mathrm{~A}-1 \mathrm{D}$ ) calibrated in $\mathrm{IU} / \mathrm{mL}$ against this research reagent and a negative plasma control in duplicate were also included in this panel (Sample 13).

\section{Participant blood establishments and laboratories}

On 25 February 2021, we sent an email invitation to join this study to 19 blood establishments and associated laboratories involved in SUPPORT-E project (https:// www.support-e.eu). The reference panel constructed at our laboratory Lref in England (Table 1) was sent to 11 laboratories in eight countries who responded positively to our invitation (Table 2). These included one laboratory each in Denmark, Estonia, the Netherlands, Norway, Slovenia and Spain, three laboratories in Belgium and two in France. Samples were tested by their respective in-house live virus microneutralisation assay against the non-variant SARS-CoV-2 strain $(n=12$ laboratories), Alpha isolates (Phylogenetic Assignment of Named Global Outbreak (Pango) lineage designation B.1.1.7; $n=3$ ) or Beta isolates (lineage B.1.351; $n=1$ ) following their normal laboratory practises. Results were expressed as end-point titres $(n=3)$ or as extrapolated median $50 \%$ tissue culture infectious dose $\left(\right.$ TCID $\left._{50}\right)$ values $(n=9)$.

\section{Detection of neutralising antibodies}

To assess assay specificity, all 12 laboratories measured virus-neutralising antibody titres for two replicates of the anti-SARS-CoV-2-negative sample against the non-variant SARS-CoV-2 strain (Sample 13). Nine laboratories reported neutralisation titres below the negative cut-off range; however, L12 reported low titres in both replicates and two laboratories (L8 and L13) reported low/medium titres in both replicates, indicating possible specificity issues in ca a quarter of participating laboratories.

\section{Linearity of neutralising antibody testing}

Linearity of neutralising antibody quantification was assessed by testing a serial dilution of a high-titre anti-SARS-CoV-2 sample, calibrated in IU/mL (Samples $1 A-1 D)$. Linear regression was used to assess correlation coefficients of log-transformed plasma dilutions and antibody titres. Neutralisation titres showed a linear relationship with dilution in the results from nine of the 12 laboratories and very high correlation coefficients $\left(R^{2}>0.975\right)$ between log transformed values (Figure $1 \mathrm{~A}$ ), even though the absolute titres reported by the laboratories varied over a 10 -fold range. Results from one laboratory (L12) showed non-linearity for the undiluted, highest titre sample, L13 showed a non-linear relationship between titre and dilution even though the correlation co-efficient was high $\left(R^{2}=0.96\right)$, while L8 showed little relationship between titre and dilution $\left(R^{2}=0.46\right)$ (Supplementary Table S1). Two of the laboratories used a smaller multiplicity of infection (describing the amount of virus used to infect a single cell: 0.0025 for L8 and 0.002 for L14) than most other laboratories. 
Details for live SARS-CoV-2 microneutralisation assays performed in 96-well plates, included in this study, Europe, AprilMay 2021 ( $\mathrm{n}=12$ laboratories)

\begin{tabular}{|c|c|c|c|c|c|c|c|c|c|}
\hline Laboratory & $\begin{array}{l}\text { Cell } \\
\text { line }^{\mathrm{a}}\end{array}$ & $\begin{array}{l}\text { Cells per } \\
\text { well }\end{array}$ & $\begin{array}{l}\text { When were cells added to } \\
\text { the } 96 \text {-well plate? }\end{array}$ & Virus per well & $\mathrm{MOI}$ & $\begin{array}{l}\text { Length of } \\
\text { incubation }\end{array}$ & $\begin{array}{l}\text { Assay } \\
\text { read-out }\end{array}$ & $\begin{array}{c}\text { Assay } \\
\text { cut-off } \\
\text { titre }\end{array}$ & Virus lineage \\
\hline Lref & VERO E6 & 10,000 & $\begin{array}{l}\text { After incubation of } \\
\text { plasma with virus }\end{array}$ & $50 \mathrm{TCID}_{50}$ & 0.005 & $\begin{array}{l}4 \text { days at } \\
37^{\circ} \mathrm{C}\end{array}$ & CPE & $<1: 40$ & B (D614) \\
\hline L2 & VERO E6 & 20,000 & $\begin{array}{l}\text { After incubation of } \\
\text { plasma with virus }\end{array}$ & $100 \mathrm{TCID} 50$ & 0.005 & $\begin{array}{l}5 \text { days at } \\
37^{\circ} \mathrm{C}\end{array}$ & CPE & $<1: 20$ & B.1 (D614) \\
\hline L3 & VERO E6 & $15,000^{c}$ & $\begin{array}{c}\text { Preseeded } 72 \mathrm{~h} \text { before } \\
\text { experiment }\end{array}$ & $100 \mathrm{TCI} D_{50}$ & 0.00667 & $\begin{array}{c}5 \text { days at } \\
37^{\circ} \mathrm{C}\end{array}$ & CPE & $<1: 20$ & B.1 (G614) \\
\hline L4 & VERO E6 & 16,000 & $\begin{array}{c}\text { Preseeded } 24 \mathrm{~h} \text { before } \\
\text { experiment }\end{array}$ & 300 TCID50 & 0.01875 & 24 h at $37^{\circ} \mathrm{C}$ & $\begin{array}{c}\text { N-protein } \\
\text { ELISA }^{\mathrm{d}}\end{array}$ & $<1: 10$ & B.1.1 (G614) \\
\hline L6 & VERO E6 & $20,000^{c}$ & $\begin{array}{c}\text { Preseeded } 24 \mathrm{~h} \text { before } \\
\text { experiment }\end{array}$ & $100 \mathrm{TCI}_{50}$ & 0.005 & $48 \mathrm{~h}$ at $37^{\circ} \mathrm{C}$ & $\begin{array}{l}\text { N-protein } \\
\text { ELISA }^{d}\end{array}$ & $<1: 40$ & B.1.1.5 (G614) \\
\hline L8 & VERO E6 & 40,000 & $\begin{array}{c}\text { After incubation of } \\
\text { plasma with virus }\end{array}$ & $100 \mathrm{PFU}$ & 0.0025 & $\begin{array}{l}4 \text { days at } \\
37^{\circ} \mathrm{C}\end{array}$ & CPE & $<1: 4$ & B.1.1 (G614) \\
\hline L9 & VERO E6 & 10,000 & $\begin{array}{c}\text { Preseeded } 24 \mathrm{~h} \text { before } \\
\text { experiment }\end{array}$ & 100 TCID 50 & 0.01 & $\begin{array}{l}5 \text { days at } \\
37^{\circ} \mathrm{C}\end{array}$ & CPE & $<1: 20$ & B.1.1 (G614) \\
\hline L10 & VERO E6 & 20,000 & $\begin{array}{c}\text { After incubation of } \\
\text { plasma with virus }\end{array}$ & $100 \mathrm{TCI} D_{50}$ & 0.005 & $\begin{array}{l}3 \text { days at } \\
35^{\circ} \mathrm{C}\end{array}$ & CPE & $<1: 10$ & B.1.1 (G614) \\
\hline L11 & VERO E6 & 10,000 & $\begin{array}{c}\text { Preseeded } 24 \mathrm{~h} \text { before } \\
\text { experiment }\end{array}$ & 100 TCID 50 & 0.01 & $\begin{array}{l}3 \text { days at } \\
37^{\circ} \mathrm{C}\end{array}$ & $\begin{array}{c}\text { N-protein } \\
\text { ELISA }^{d}\end{array}$ & $<1.0$ & B (D614) \\
\hline L12 & VERO & 16,000 & $\begin{array}{l}\text { After incubation of } \\
\text { plasma with virus }\end{array}$ & 100 TCID50 & 0.00625 & $\begin{array}{l}4 \text { days at } \\
37^{\circ} \mathrm{C}\end{array}$ & CPE & $<1: 20$ & B.1.153 (G614) \\
\hline L13 & VERO E6 & 20,000 & $\begin{array}{l}\text { After incubation of } \\
\text { plasma with virus }\end{array}$ & $400 \mathrm{PFU}$ & 0.02 & $\begin{array}{l}5 \text { days at } \\
37^{\circ} \mathrm{C}\end{array}$ & CPE & $<1: 50$ & $A(D 614)$ \\
\hline L14 & VERO E6 & 50,000 & $\begin{array}{c}\text { Preseeded } 24 \mathrm{~h} \text { before } \\
\text { experiment }\end{array}$ & $100 \mathrm{TCI}_{50}$ & 0.002 & $\begin{array}{l}5 \text { days at } \\
37^{\circ} \mathrm{C}\end{array}$ & CPE & $<1: 20$ & B.1.153 (G614) \\
\hline
\end{tabular}

CPE: cytopathic effect; MOI: multiplicity of infection; TCID50: median tissue culture infectious dose; PFU: plaque-forming units; TICD50: median tissue culture infectious dose.

a All cell lines obtained from the American Type Culture Collection (Manassas, United States) and free from mycoplasma contamination: VERO E6 \#CRL-1586 and VERO \#CCL81.

${ }^{\mathrm{b}} \mathrm{MOI}$ was calculated based on the amount of virus (TCID50 or PFU) used for infection.

c Cell count at the time of seeding.

${ }^{d}$ In-house ELISA where commercially obtained antibody against the nucleocapsid is used to quantify the virus replication.

Neutralising antibody titres on positive plasma samples provided in duplicate (Samples 12, 7, 2 and 19) showed moderate reproducibility between replicates (Figure $1 \mathrm{~B}$ ). The remaining results showed a wide range of titres that may have arisen, at least in part, from different testing methods as presented in Table 2; for example, assay titres reported by L13 were consistently higher than those reported by other laboratories, while those from L11 were consistently lower. Variability between results reported by different laboratories were often large; L11 reported a neutralising antibody titre of $1: 20 / 1: 40$ to sample 12 whereas L13 reported a titre $1: 1,455 / 1: 1,165$ to this same sample.

\section{Normalisation of neutralising antibody level measurements}

The neutralising antibody results were calibrated in relation to a standard curve obtained by testing of a dilution series calibrated in $\mathrm{IU} / \mathrm{mL}$. Neutralisation titres from each assay were converted to $\mathrm{IU} / \mathrm{mL}$ using linear regression formulae derived from assay calibration with the pre-quantified control as shown in Figure
$1 \mathrm{~A}$. The conversion used derived assay-specific multipliers and constants listed in Supplementary Table S1. Results from L8 and L12 were excluded from normalisation because they lacked linearity, and L13 was excluded for non-proportionality on testing the dilution series. Normalised quantitation of antibody levels showed moderate reproducibility between replicates (Figure $1 \mathrm{C}$ ) and more than 10 -fold reduced inter-laboratory variability compared with raw titres (Figure 2). Furthermore, testing of the 1:10 diluted NIBSC reagent yielded a median neutralising antibody concentration of $133 \mathrm{IU} / \mathrm{mL}$ after normalisation, which was close to the expected $130 \mathrm{IU} / \mathrm{mL}$ value and also demonstrated low variability between assays (interquartile range: 87-169, <2-fold).

\section{Neutralising antibody titres against SARS- CoV-2 variants}

Three participating laboratories (Lref, L3 and L9) reported neutralisation titres with the SARS-CoV-2 variant Alpha (lineage B.1.1.7) and one laboratory (L3) with variant Beta (lineage B.1.351). For Samples 12, 7, 


\section{FIGURE 1}

Neutralising antibody titres for SARS-CoV-2 in the plasma sample panel, Europe, April-May 2021 ( $\mathrm{n}=12$ laboratories)

A. Linearity of antibody testing

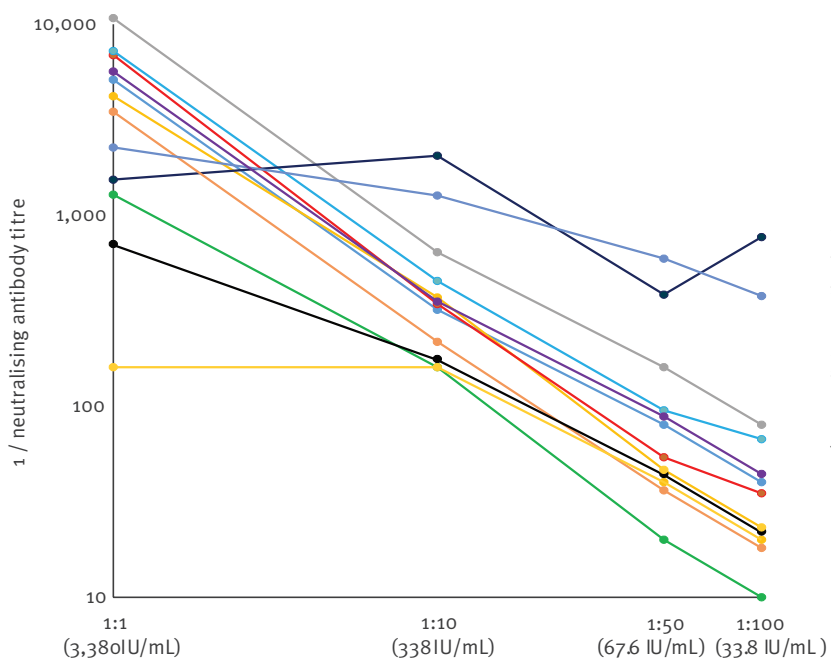

Calibrated sample dilution

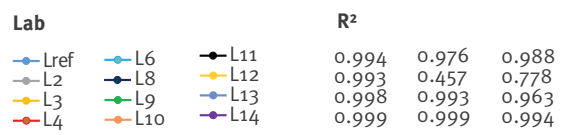

C. Normalisation of antibody levels

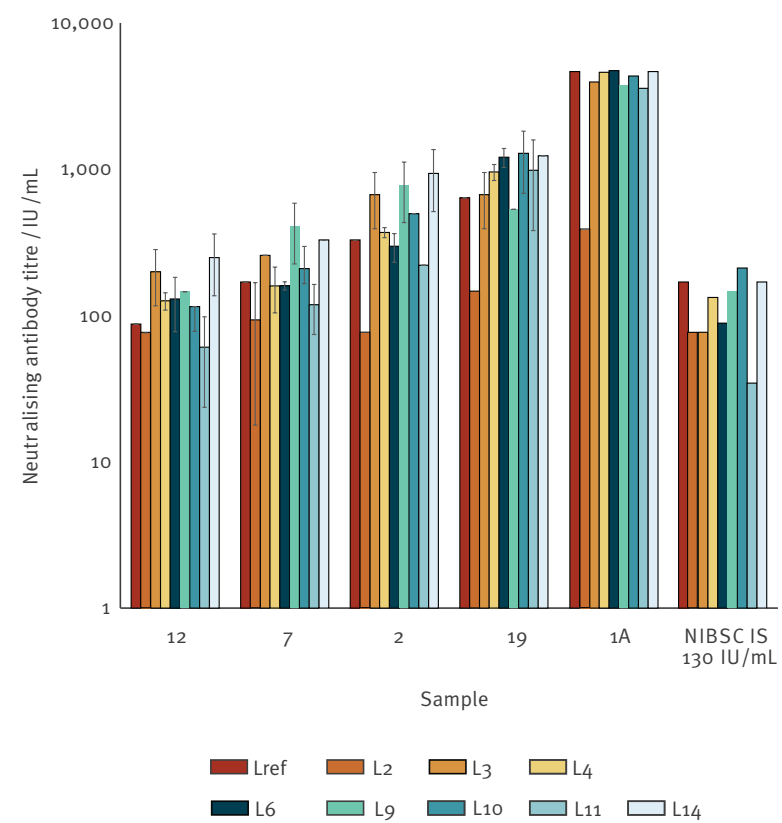

B. Reproducibility of antibody testing

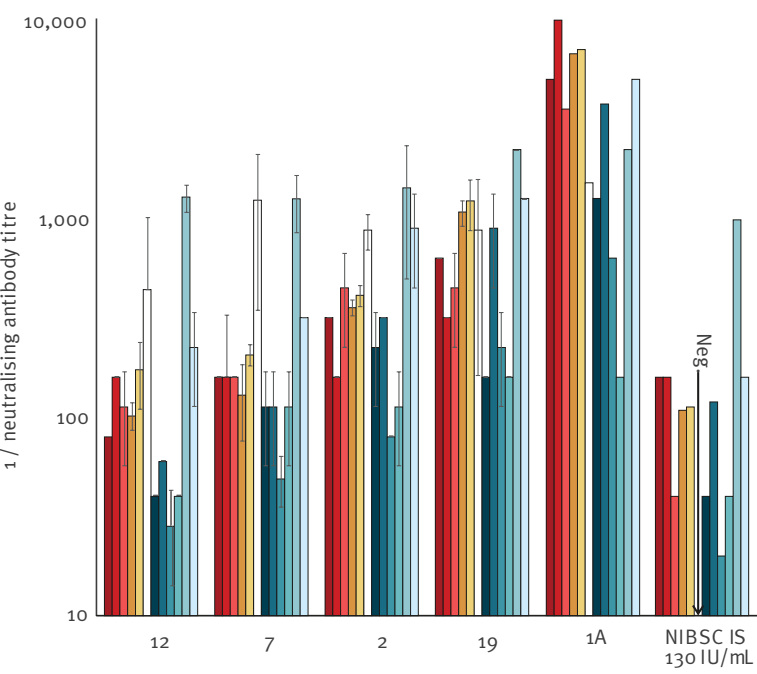

Sample

$$
\begin{aligned}
& \square \text { Lref } \square \text { L2 } \square \text { L3 } \square \text { L4 } \square \text { L6 } \square \text { L8 } \\
& \text { L9 } \quad \square \text { L11 } \square \text { L12 } \square \text { L13 } \square \text { 14 }
\end{aligned}
$$

D. Antibody titres to virus variants

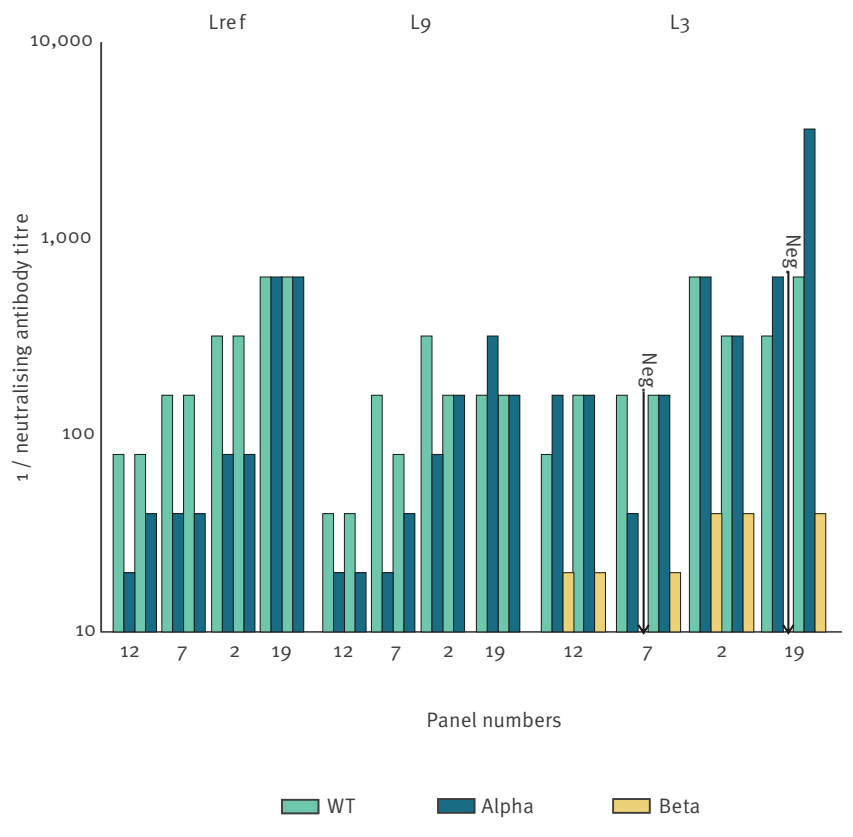

IS: internal standard; IU: international unit; NIBSC: National Institute for Biological Standards and Control; SARS-CoV-2: severe acute respiratory syndrome coronavirus 2; WT: non-variant SARS-CoV-2 strain.

A. Linearity of neutralising antibody testing assessed by testing a dilution series (Samples 1A-1D). For results expressed as end-point dilutions, any overlapping graph lines were minimally offset to separate the depicted titres.

B. Neutralising antibody titres for convalescent samples included in the panel; bar heights show geometric means for Samples 12, 7, 2 and 19 tested in two replicates per sample and error bars show standard deviations.

C. Normalised neutralising antibody levels after conversion to IU/mL. Neutralisation titres from each assay were converted to IU/mL using linear regression formulae derived from assay calibration with the pre-quantified control shown in panel A. The conversion used derived assay-specific multipliers and constants listed in Supplementary Table S1. Error bars show standard deviations. The poor correlation of reported antibody titres with dilution of the pre-quantified control reported by L8, L12 and L13 precluded their inclusion in the depiction of normalised antibody levels.

D. Neutralising antibody titres assessed with SARS-CoV-2 Alpha (B.1.1.7) and Beta (B.1.351) variants. 
Range of reported raw neutralising antibody titres and normalised titres, Europe, April-May 2021 (n=12 laboratories)

A. Reported antibody titres

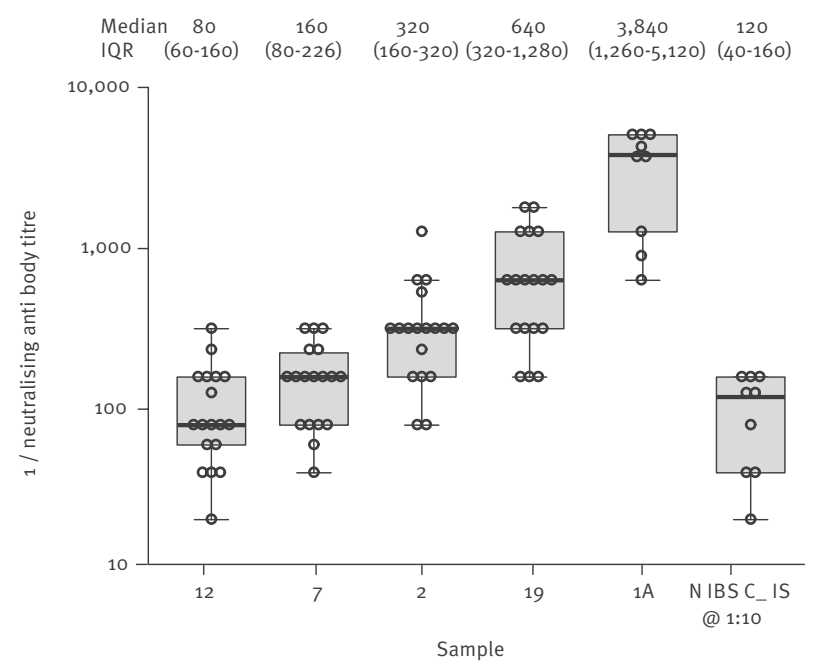

B. Normalised quantitation

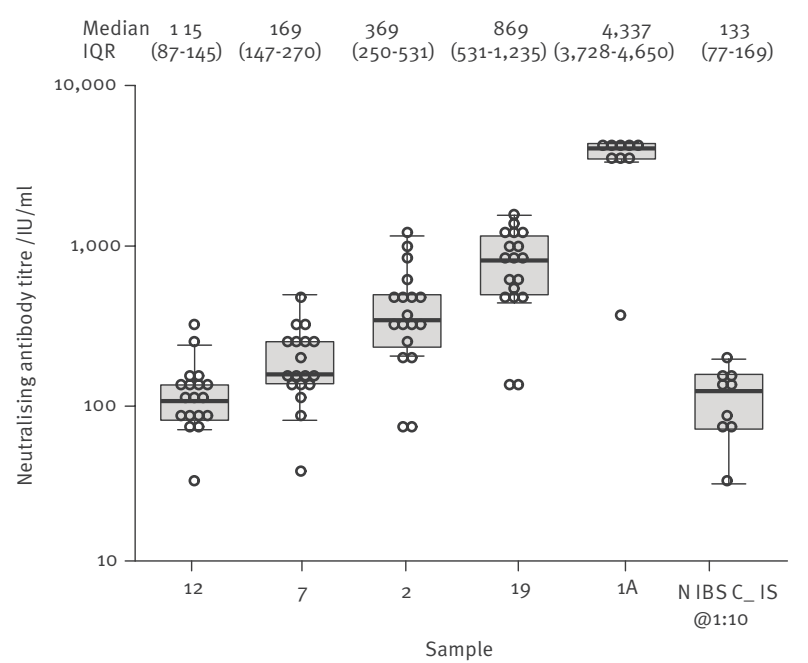

IQR: interquartile range; NIBSC_IS: National Institute for Biological Standards and Control internal standard; SARS-CoV-2: severe acute respiratory syndrome coronavirus 2 .

The laboratories tested a panel of four convalescent plasma samples in duplicate, one in singular and an NIBSC research reagent at a concentration of $130 \mathrm{IU} / \mathrm{mL}$. Results from L8, L12 and L13 have been excluded from normalisation the results lacked linearity and these data are therefore not included in panel $A$.

2 and 19, antibody titres were typically lower against Alpha strains than against non-variant virus (Figure $1 \mathrm{D})$; these differences were less marked in Lref and L9 than in L3. Reported neutralising antibody levels against the antigenically more distinct Beta strain were substantially lower than against non-variant SARS-CoV-2.

\section{Ethical statement}

All samples were obtained via the non-clinical services from NHS Blood and Transplant, England. Signed donor consent was obtained for purposes of clinical audit and research, as well as to assess and improve the services including diagnostic testing.

\section{Discussion}

Our analysis demonstrates that normalisation and standardisation using internal controls is achievable for virus neutralisation assays employing a wide range of formats. It should be used to support not only the harmonisation of antibody concentrations present in convalescent plasma supplied for clinical use and trials but also for the assessment of its efficacy. Our data also demonstrated clearly that neutralising antibody levels in our panel samples were generally lower against Beta strains than against non-variant SARSCoV-2 isolates. These data are consistent with previously published observations that the spike mutations in Beta, and to a lesser extent also in Alpha, variants are associated with reduced susceptibility to neutralising antibodies [13-15]. Therefore, these must be considered in data analysis, especially when SARS-CoV-2 variants have emerged during the convalescent plasma trial periods $[11,16,17]$. Further international standards and harmonisations are required for each SARS-CoV-2 variant of concern.

It is a limitation of our study that we used plasma samples only and that we did not compare the microneutralisation assay with a plaque reduction neutralisation test (PRNT) which has been shown to be more sensitive in detecting neutralising antibodies [18]. As all participating laboratories had introduced a microneutralisation assay for convalescent plasma testing, we felt that evaluation of PRNT assay or serum samples was less relevant in this study. However, it is important to note the potential differences in neutralising antibody titres obtained by PRNT and microneutralisation assay can also be overcome by harmonisation of those readings into $\mathrm{IU} / \mathrm{mL}$.

\section{Conclusions}

Our data demonstrate substantial heterogeneity in neutralising antibody testing used to determine antibody content in convalescent plasma donations across Europe. This is not surprising as this gold standard method was mostly used as a research tool before the COVID-19 pandemic and has only recently been subjected to standardisation [12]. Although we observed almost 100 -fold differences in raw neutralising antibody titres between the participating laboratories, these readings could largely be harmonised by adopting the NIBSC international standard. As many convalescent plasma trials have either been previously reported or are approaching their endpoints, a large meta-analysis is urgently required that focuses on 
identifying the efficacy of convalescent plasma based on neutralising antibody dose. The harmonisation and quantification of neutralising antibody testing is a first step towards determining a cut-off for protective and therapeutic levels of neutralising antibodies present in convalescent plasma. It is also an essential tool when using neutralising antibody data to assess and compare vaccine effectiveness from different SARS-CoV-2 vaccine candidates and clinical trials.

\section{Acknowledgements}

We would like to thank Birgit Knudsen and Christine Isnard for their excellent technical assistance.

Funding: This study was supported by the European Commission (SUPPORT-E, grant number 101015756).

\section{Conflict of interest}

None declared.

\section{Authors' contributions}

$\mathrm{H}$ Harvala coordinated the experiments, analysed the data and wrote the first draft of manuscript; D Nguyen prepared the panel of samples and its shipment, and helped to organise the data; P Simmonds performed the statistical analysis and constructed figures; M Steenhuis, E Wouters, H Schrezenmeier, HB Feys and C Ellen van der Schoot contributed to study design and panel composition. D Desmecht, M Garigliany, M Romano, C Barbezange, P Maes, B Van Holm, J Mendoza, S Oyonarte, A Fomsgaard, R Lassaunière, E Zusinaite, K Resman Rus, T Avšič-Županc, JHJ Reimerink, F Brouwer, M Hoogerwerf, CBEM Reusken, G Grodeland, S Le Cam, P Gallian, A Amroun, N Brisbarre, C Martinaud, I Leparc Goffart and D Nguyen did the testing and reported their results back to this study. All authors reviewed their data and critically revised the paper, as well as approved the final version of the paper.

\section{References}

1. Kellam P, Barclay W. The dynamics of humoral immune responses following SARS-CoV-2 infection and the potential for reinfection. J Gen Virol. 2020;101(8):791-7. https://doi. org/10.1099/jgv.0.001439 PMID: 32430094

2. Wajnberg A, Amanat F, Firpo A, Altman DR, Bailey MJ, Mansour $M$, et al. Robust neutralizing antibodies to SARS-CoV-2 infection persist for months. Science. 2020;370(6521):1227-30. https://doi.org/10.1126/science.abd7728 PMID: 33115920

3. McMahan K, Yu J, Mercado NB, Loos C, Tostanoski LH, Chandrashekar A, et al. Correlates of protection against SARSCoV-2 in rhesus macaques. Nature. 2021;590(7847):630-4. https://doi.org/10.1038/s41586-020-03041-6 PMID: 33276369

4. Rogers TF, Zhao F, Huang D, Beutler N, Burns A, He WT, et al. Isolation of potent SARS-CoV-2 neutralizing antibodies and protection from disease in a small animal model. Science. 2020;369(6506):956-63. https://doi.org/10.1126/science. abc7520 PMID: 32540903

5. Khoury DS, Cromer D, Reynaldi A, Schlub TE, Wheatley AK Juno JA, et al. Neutralizing antibody levels are highly predictive of immune protection from symptomatic SARS-CoV-2 infection. Nat Med. 2021. https://doi.org/10.1038/s41591-021-01377-8 PMID: 34002089

6. Taylor PC, Adams AC, Hufford MM, de la Torre I, Winthrop K, Gottlieb RL. Neutralizing monoclonal antibodies for treatment of COVID-19. Nat Rev Immunol. 2021;21(6):382-93. https://doi. org/10.1038/S41577-021-00542-x PMID: 33875867
7. Piechotta V, Iannizzi C, Chai KL, Valk SJ, Kimber C, Dorando E, et al. Convalescent plasma or hyperimmune immunoglobulin for people with COVID-19: a living systematic review. Cochrane Database Syst Rev. 2021;5(5):CD013600. PMID: 34013969

8. Focosi D. Franchini M. Potential use of convalescent plasma for SARS-CoV-2 prophylaxis and treatment in immunocompromised and vulnerable populations. Expert Rev Vaccines. 2021;1-8. PMID: 34015243

9. Libster R, Pérez Marc G, Wappner D, Coviello S, Bianchi A, Braem V, et al. Early high-titer plasma therapy to prevent severe Covid-19 in older adults. N Engl J Med. 2021;384(7):6108. https://doi.org/10.1056/NEJMoa2033700 PMID: 33406353

10. Hueso T, Pouderoux C, Péré H, Beaumont AL, Raillon LA, Ader F, et al. Convalescent plasma therapy for B-cell-depleted patients with protracted COVID-19. Blood. 2020;136(20):2290-5. https://doi.org/10.1182/blood.2020008423 PMID: 32959052

11. Körper S, Weiss M, Zickler D, Wiesmann T, Zacharowski K, M.Corman V, et al. High dose convalescent plasma in COVID-19: results from the randomized trial CAPSID. medRxiv. 2021:2021.05.10.21256192.

12. Kristiansen PA, Page M, Bernasconi V, Mattiuzzo G, Dull P, Makar K, et al. WHO International Standard for anti-SARSCoV-2 immunoglobulin. Lancet. 2021;397(10282):1347-8. https://doi.org/10.1016/S0140-6736(21)00527-4 PMID: 33770519

13. Cele S, Gazy I, Jackson L, Hwa SH, Tegally H, Lustig G, et al. Escape of SARS-CoV-2 501Y.V2 from neutralization by convalescent plasma. Nature. 2021;593(7857):142-6. https:// doi.org/10.1038/s41586-021-03471-w PMID: 33780970

14. Wibmer CK, Ayres F, Hermanus T, Madzivhandila M, Kgagudi $\mathrm{P}$, Oosthuysen $\mathrm{B}$, et al. SARS-CoV-2 501Y.V2 escapes neutralization by South African COVID-19 donor plasma. Nat Med. 2021;27(4):622-5. https://doi.org/10.1038/s41591-02101285-X PMID: 33654292

15. Harvey WT, Carabelli AM, Jackson B, Gupta RK, Thomson EC, Harrison EM, et al. SARS-CoV-2 variants, spike mutations and immune escape. Nat Rev Microbiol. 2021;19(7):409-24. https://doi.org/10.1038/S41579-021-00573-0 PMID: 34075212

16. Abani O, Abbas A, Abbas F, Abbas M, Abbasi S, Abbass H, et al. Convalescent plasma in patients admitted to hospital with COVID-19 (RECOVERY): a randomised controlled, open-label, platform trial. Lancet. 2021;397(10289):2049-59. https://doi. org/10.1016/S0140-6736(21)00897-7 PMID: 34000257

17. Ratcliff J, Nguyen D, Fish M, Rynne J, Jennings A, Williams S, et al. Virological and serological characterization of critically ill patients with COVID-19 in the UK: Interactions of viral load, antibody status and B.1.1.7 variant infection. J Infect Dis. 2021;jiab283. https://doi.org/10.1093/infdis/jiab283 PMID: 34031695

18. Perera RA, Mok CK, Tsang OT, Lv H, Ko RL, Wu NC, et al. Serological assays for severe acute respiratory syndrome coronavirus 2 (SARS-CoV-2), March 2020. Euro Surveill. 2020;25(16):2000421. https://doi.org/10.2807/1560-7917. ES.2020.25.16.2000421 PMID: 32347204

\section{License, supplementary material and copyright}

This is an open-access article distributed under the terms of the Creative Commons Attribution (CC BY 4.0) Licence. You may share and adapt the material, but must give appropriate credit to the source, provide a link to the licence and indicate if changes were made.

Any supplementary material referenced in the article can be found in the online version.

This article is copyright of the authors or their affiliated institutions, 2021. 